\title{
Estimation of changes in genetic parameters in selected lines of mice using REML with an animal model. 1. Lean mass
}

\author{
B. K. BENIWAL, *ł I. M. HASTINGS, ${ }^{*}$ R. THOMPSON $† \&$ W. G. HILL*§ \\ *Institute of Cell, Animal and Population Biology, University of Edinburgh, West Mains Road, Edinburgh EH9 3JT and \\ TAFRC Institute of Animal Physiology and Genetics Research, Edinburgh Research Station, Roslin, Midlothian \\ EH25 9PS, Scotland
}

\begin{abstract}
Analysis was undertaken using Restricted Maximum Likelihood (REML) with an animal model of the results of selection for 20 generations for predicted lean mass in 10-week-old male mice. There were three replicates, each comprising high, low and unselected control lines. The overall estimates of heritability $\left(h^{2}\right)$ and common environmental correlations $\left(c^{2}\right)$ from results of the first seven generations were $0.51 \pm 0.03$ and $0.21 \pm 0.01$, respectively. Analyses of data from different lines and different numbers of generations were undertaken but with all pedigrees and data included, which enabled inferences to be drawn on changes in variance that were not due simply to inbreeding or short-term effects of selection. Estimates of $h^{2}$ were lower in selected lines than the control, increasingly so in later generations, indicating departure from the infinitesimal model assumption of unlinked additive genes each of very small effect. In addition, values of $c^{2}$ became higher in high than in control or low selected lines.
\end{abstract}

Keywords: body size, heritability, infinitesimal model, maximum likelihood, mouse, selection.

\section{Introduction}

In the analysis of data spanning more than one generation, the estimation of genetic parameters, such as heritability, and the prediction of breeding values in farm livestock, are generally based on the assumption that data on relatives are multivariate normally distributed and satisfy the infinitesimal genetic model. This requires an infinite number of unlinked genes of small effect, such that selection does not change the variance as a consequence of gene frequency change but only by inducing transient gametic disequilibrium, and variance within families changes only in proportion to the inbreeding coefficient of the parent (Bulmer, 1980). For livestock with long generation intervals, changes in variance and heritability over many generations cannot be estimated, but this opportunity exists with laboratory animals. Data were available spanning almost 40 generations on lines of mice selected for body weight and lean growth. These were analysed with the aim of

Present address: Rajasthan Agricultural University, College of Veterinary and Animal Science, Bikaner-334 001, India.

§Correspondence. finding out how much variances changed during the selection and how well the infinitesimal model held.

Maximum likelihood methods enable the best use to be made of all available data, and estimates from Restricted Maximum Likelihood (REML).(Patterson \& Thompson, 1971) are unbiased by the presence of fixed effects. By fitting an animal model, in which the phenotype of each animal is expressed in terms of its breeding value and other random effects and the variances and covariance of observations are specified by use of a relationship matrix, all information is included and properly weighted. Furthermore, the animal model enables parameters of the base population to be estimated without bias, despite selection and finite population size, provided that the pedigrees are complete, all data on which selection is practised are included, and the infinitesimal model holds (Sørensen \& Kennedy, 1984; van der Werf \& de Boer, 1990). Thus, under the infinitesimal model, estimates of the genetic variance in the base population have the same expectation whether data are taken from unselected or selected lines, or from a few or many generations. By taking different datasets from the selection experiments, the model can be tested in this way. 
This paper describes the analysis of lines of mice ( $\mathrm{P}$ lines) selected for 20 generations on an index of lean mass, with replications and unselected controls. Subsequently selection was practised without replication for body weight, and the analysis of these data, including a discussion of an apparent selection plateau, is described in a second paper (Beniwal et al., 1992). Litter size was recorded each generation, and the estimation of its genetic parameters and their changes are also reported in a second paper. Analyses using similar methods on another set of lines selected for food intake from the same base population have been published previously (Meyer \& Hill, 1991).

\section{Materials and methods}

\section{Animals}

The $\mathrm{P}$ lines were established from a three-way cross base: two inbreds were intercrossed, their $F_{1}$ was crossed to an outbred line, and generation 0 followed one generation of random mating. Each of the three replicates was derived from a different set of full sib families. High, low and unselected control lines of each replicate were started from the same families. A full account of the origins and response in early generations is given by Sharp et al. (1984). Sixteen full sib families were maintained per line for the first seven generations, and subsequently eight families per line. Selection was practised within families and mating was by the maximum avoidance scheme of Falconer (1973); near relatives were used to make up losses through death or infertility. Numbers reared per litter were restricted where possible to a range $6-12$ by cross fostering and culling.

Selection was practised for a simple phenotypic index of predicted lean mass, more strictly non-fat mass of males at 10 weeks of age, which is referred to simply as lean mass $(L M)$.

$L M=B W \quad($ body weight $)-8 \times F W \quad($ gonadal fat pad weight),

because approximately one-eighth of the body fat is contained in the gonadal pads. Males were mated prior to recording and litters retained only from selected males. Four males per family were recorded in the high and low selected lines, two in the controls.

\section{Statistical methods}

Analysis of lean mass was undertaken for the animal model using the derivative-free REML package of Meyer (1988). Standard errors were computed from the second derivative of the natural log likelihood around the maximum. The model was
$\mathbf{y}=\mathbf{X b}+\mathbf{Z a}+\mathbf{W c}+\mathbf{e}$

where $\mathbf{y}$ is the vector of observations; $\mathbf{b}$ is the vector of fixed effects, including generations, replicates and litter size at birth; $\mathbf{a}$ is the vector of additive genetic effects of individuals, with $\operatorname{var}(\mathbf{a})=\mathbf{A} V_{\mathrm{A}}$, where $\mathbf{A}$ is the numerator relationship matrix and $V_{\mathrm{A}}$ is the additive genetic variance; $\mathbf{c}$ is the vector of litter effects, with $\operatorname{var}(\mathbf{c})=\mathbf{I} V_{\mathrm{C}}$, where $V_{\mathrm{C}}$ is the common family environment or litter variance and $I$ is the identity matrix; $\mathbf{e}$ is the vector of random environmental effects, with $\operatorname{var}(\mathbf{e})=\mathrm{I} V_{\mathrm{E}}$, where $V_{\mathrm{E}}$ is the environmental variance; $\mathbf{a}, \mathbf{c}$ and $\mathbf{e}$ all have mean zero and are uncorrelated; $\mathbf{X}$, $\mathbf{Z}$ and $\mathbf{W}$ are incidence matrices. Furthermore: $V_{\mathrm{P}}=V_{\mathrm{A}}+V_{\mathrm{C}}+V_{\mathrm{E}}$ is the phenotypic variance; $h^{2}=$ $V_{\mathrm{A}} / V_{\mathrm{P}}$ is the (narrow sense) heritability; $c^{2}=V_{\mathrm{C}} / V_{\mathrm{P}}$ is the proportion of variance from common family environment (' $c$-square' coefficient).

When data were analysed separately for each replicate, generations but not lines were fitted in the model because high, low and control lines of each replicate were derived from the same base families and were contemporaneous; whereas when data for each direction of selection from all three replicates were analysed, both generations and replicates were fitted because they did not have the same base families.

All analyses included pedigrees back to the base population, incorporating all animals including the female parents with no records on the trait under selection. The numbers of records, animals and litters for different datasets analysed are given in Table 1 , the total comprises records on 5,792 mice from 1,858 litters. Initially analyses were done on the first seven generations to give base population estimates; subsequently the data on 20 generations were used in various combinations.

Preliminary analyses gave different estimates of genetic and common environment variance in, for example, high and control lines when analysed separately. These analyses, however, do not utilize the divergence between lines caused by selection, and so are not efficient. In order to incorporate the genetic change but eliminate environmental effects common to generation, a model was fitted in which the variances in a pair of different lines or over different generations were not assumed to be the same. The method followed that of Visscher \& Thompson (1990). Let $\mathbf{A}=\mathbf{T D T}$, where $\mathbf{T}$ is lower triangular and describes the transfer of genes from one generation to the next, and $\mathbf{D}$ is diagonal and represents the variancecovariance matrix of Mendelian sampling terms in the two lines or groups of lines, e.g. high and control lines,

$\mathbf{D}=\left[\begin{array}{cc}\mathbf{D}_{1} & 0 \\ 0 & \mathbf{D}_{2}\end{array}\right]$ 
Then

$$
\begin{aligned}
V(\mathbf{a}) & =\mathbf{T}\left[\begin{array}{cc}
\mathbf{D}_{1} & \mathbf{0} \\
\mathbf{0} & \mathbf{0}
\end{array}\right] \mathbf{T}^{\prime} V_{\mathrm{A} 1}+\mathbf{T}\left[\begin{array}{cc}
\mathbf{0} & \mathbf{0} \\
\mathbf{0} & \mathbf{D}_{2}
\end{array}\right] \mathbf{T}^{\prime} V_{\mathrm{A} 2} \\
& =\mathbf{A}_{1} V_{\mathrm{A} 1}+\mathbf{A}_{2} V_{\mathrm{A} 2} .
\end{aligned}
$$

Table 1 Number of Records (Rec.), Animals (Anim.) and Litters (Lit.) in datasets of 0-7 and 0-20 generations used in

\begin{tabular}{|c|c|c|c|c|c|c|}
\hline \multirow[b]{2}{*}{ Lines } & \multicolumn{3}{|c|}{ Generations 0-7 } & \multicolumn{3}{|c|}{ Generations $0-20$} \\
\hline & Rec. & Anim. & Lit. & Rec. & Anim. & Lit. \\
\hline $\begin{array}{l}\text { Replicate } 1 \\
\qquad(\mathrm{C}+\mathrm{H}+\mathrm{L}) \dagger\end{array}$ & 1081 & 1482 & 336 & 1964 & 2652 & 635 \\
\hline $\begin{array}{l}\text { Replicate } 2 \\
\qquad(\mathrm{C}+\mathrm{H}+\mathrm{L})\end{array}$ & 1043 & 1437 & 329 & 1925 & 2597 & 624 \\
\hline $\begin{array}{l}\text { Replicate } 3 \\
\qquad(\mathrm{C}+\mathrm{H}+\mathrm{L})\end{array}$ & 1024 & 1398 & 315 & 1903 & 2545 & 599 \\
\hline $\begin{array}{l}\text { Control } \\
\quad(\text { Rep. } 1+2+3)\end{array}$ & 824 & 1271 & 347 & 1417 & 2134 & 622 \\
\hline $\begin{array}{l}\text { High } \\
\qquad(\operatorname{Rep} .1+2+3)\end{array}$ & 1370 & 1826 & 369 & 2418 & 3156 & 664 \\
\hline $\begin{array}{l}\text { Low } \\
\quad(\operatorname{Rep} .1+2+3)\end{array}$ & 1334 & 1792 & 366 & 2337 & 3076 & 668 \\
\hline Overall & 3134 & 4317 & 980 & 5792 & 7794 & 1858 \\
\hline $\begin{array}{l}\text { Control + high } \\
\quad(\text { Rep. } 1+2+3)\end{array}$ & 2004 & 2811 & 662 & 3645 & 5004 & 1238 \\
\hline $\begin{array}{l}\text { Control + low } \\
\quad(\text { Rep. } 1+2+3)\end{array}$ & 1968 & 2777 & 665 & 3564 & 4924 & 1242 \\
\hline
\end{tabular}
the analyses of lean mass at 10 weeks of age

$\dagger \mathrm{C}=$ Control, $\mathrm{H}=$ High, $\mathrm{L}=$ Low and Rep. = Replicate.

Generation 0 represents the base population and the numbers in all the replicates and lines include base animals/ records.
For illustration, consider analyses undertaken fitting $\sigma_{\mathrm{A} 1}^{2}$ to the control for generations $0-20$ and low for generations $0-4$, and $\sigma_{\mathrm{A} 2}^{2}$ to the low for generations $5-20$. Thus in the low line at generation 5, the between-family variance would be a function of $\sigma_{\mathrm{A} 1}^{2}$ and the within-family variance a function of $\sigma_{\mathrm{A} 2}^{2}$; in later generations of the line the contribution of $\sigma_{\mathrm{A} 2}^{2}$ would become relatively higher from successive Mendelian samplings, such that, ignoring the selection and finite population size, the total genetic variance would be $\left(\frac{1}{2}\right)^{t-4} V_{\mathrm{A} 1}+\left[1-\left(\frac{1}{2}\right)^{t-4}\right] V_{\mathrm{A} 2}$. When $\sigma_{\mathrm{A} 1}^{2}$ and $\sigma_{\mathrm{A} 2}^{2}$ were fitted from generation 0 in a pair of lines they were assumed different from the outset, even though the base-selected animals of each line were full sibs.

Heterogeneity of litter variance was included similarly as $V(\mathbf{c})=\mathbf{I}_{1} V_{\mathrm{C} 1}+\mathbf{I}_{2} V_{\mathrm{C} 2}$ is some analyses. When more parameters are fitted the computing needed to maximize the likelihood is substantially increased, and so models incorporating heterogeneity of $V_{\mathrm{A}}$ or $V_{\mathrm{C}}$ were not run on all datasets.

\section{Results}

\section{Responses}

The mean lean mass of males for each line and generation is shown in Fig. 1. At generation 20 the means, standard deviations and coefficients of variation averaged over replicates were, respectively: high $38.0 \mathrm{~g}, 3.0 \mathrm{~g}$ and 9.0 per cent; control $27.5 \mathrm{~g}, 2.1 \mathrm{~g}$ and 7.8 per cent; and low $23.0 \mathrm{~g}, 1.7 \mathrm{~g}$ and 7.6 per cent. Thus the divergence between high and low lines was approximately seven phenotypic standard deviations. Further details of body weights and compositions are given by Hastings \& Hill (1989) and Beniwal et al. (1992).

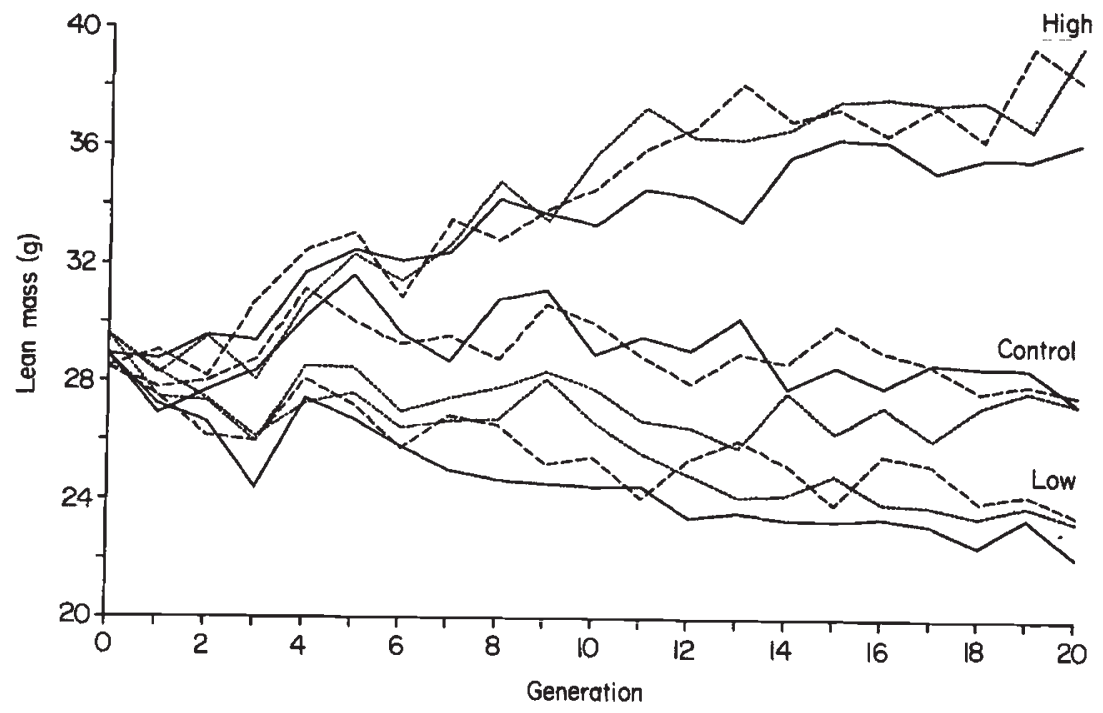

Fig. 1 Generation means for lean mass of each line. Replicate $1(\cdot \cdots \cdot \cdots \cdot \cdots), 2(-)$, $3(---)$. 


\section{Analysis of data to generation 7}

Under the assumption of homogeneous variances in different lines, estimates of variance components, $h^{2}$ and $c^{2}$ are given in Table 2. Because the means and standard deviations had not changed greatly by generation 7 , detailed results are given on untransformed data, $\log$ transformation having little effect on the partition of variance (see Table 2). As expected, estimates from the separate replicates are, within the range of sampling error, consistent with each other and with the overall estimates of $h^{2}=0.51 \pm 0.03, c^{2}=0.21 \pm 0.01$. Standard errors of estimates are higher when data on, for example, the three high lines are analysed compared to data on the three lines of one replicate, because in the former case there is no information from the divergence produced by selection. Even so, there are substantial differences between estimates of $h^{2}$ from control, high and low: 0.42, 0.27 and 0.39 , respectively. When taking selected lines with the control in pairs, estimates of $h^{2}$ are higher (0.46-0.47) than separately, but still lower than overall. Likelihood ratio tests of, for example, high versus control have not been performed as they have data in common from generation 0 .

\section{Analysis of data to generation 20}

Equivalent results to those in Table 2 for data to generation 20 are given in Table 3. Because the means and variances, but not the coefficients of variation, of the high and low lines differed greatly, the natural logtransformed results are given in full. Variances are scaled by $10^{-4}$, thus a value of $V_{\mathrm{P}}=100 \times 10^{-4}$ on the log scale implies a coefficient of variation of approximately $(100)^{1 / 2}=10$ per cent. The overall $h^{2}$ estimate is $0.52 \pm 0.02$, essentially unchanged from the analysis to generation 7 and the replicates are consistent. Although estimates of heritability from the sets of selected lines, high (0.38) and low (0.46), taken separately are lower than the overall estimate, the departure is smaller than from the equivalent analysis on the 7 generation dataset. For high and low analysed together with controls, the estimates $(0.53$ and 0.49$)$ are close to those overall. Thus this analysis suggests little change in genetic variance over generations. The estimates of common environmental variance $\left(V_{\mathrm{C}}\right)$ and correlation $\left(c^{2}\right)$ are greater in the high than low or control lines.

\section{Analysis of sub-divided data assuming heterogeneity}

Pairs of lines, high with control (Table 4) and low with control (Table 5) were analysed together with different additive genetic and common environment variances fitted in each line, so that the divergence between the lines caused by selection could be used in comparisons between them. In order to investigate in more detail how variances in the selected lines change, data were also split as, for example, control + first 7 generations of high and generations 8-20 of high. Differences

Table 2 Estimates of variance components and genetic parameters for lean mass from data of generations 0-7

\begin{tabular}{|c|c|c|c|c|c|c|c|c|}
\hline \multirow[b]{3}{*}{ Lines } & \multicolumn{6}{|c|}{ Untransformed } & \multirow{2}{*}{\multicolumn{2}{|c|}{ Log transformed }} \\
\hline & $V_{\mathrm{A}}$ & $V_{\mathrm{C}}$ & $V_{\mathrm{E}}$ & $V_{\mathrm{P}}$ & \multirow{2}{*}{$\begin{array}{l}h^{2} \\
\pm \text { s.e. }\end{array}$} & \multirow{2}{*}{$\begin{array}{l}c^{2} \\
\pm \text { s.e. }\end{array}$} & & \\
\hline & $\left(\mathrm{g}^{2}\right)$ & & & & & & $\begin{array}{l}V_{\mathrm{p}} \\
\left(\times 10^{-4}\right)\end{array}$ & $\begin{array}{l}h^{2} \\
\pm \text { s.e. }\end{array}$ \\
\hline $\begin{array}{l}\text { Rep. } 1 \\
\qquad(\mathrm{C}+\mathrm{H}+\mathrm{L})\end{array}$ & 3.81 & 1.43 & 2.92 & 8.16 & $\begin{array}{r}0.466 \\
\pm 0.047\end{array}$ & $\begin{array}{r}0.175 \\
\pm 0.015\end{array}$ & 97.8 & $\begin{array}{r}0.465 \\
\pm 0.055\end{array}$ \\
\hline $\begin{array}{l}\text { Rep. } 2 \\
\qquad(\mathrm{C}+\mathrm{H}+\mathrm{L})\end{array}$ & 5.05 & 1.96 & 2.23 & 9.24 & $\begin{array}{r}0.546 \\
\pm 0.054\end{array}$ & $\begin{array}{r}0.212 \\
\pm 0.028\end{array}$ & 108.8 & $\begin{array}{r}0.546 \\
\pm 0.049\end{array}$ \\
\hline $\begin{array}{l}\text { Rep. } 3 \\
\qquad(\mathrm{C}+\mathrm{H}+\mathrm{L})\end{array}$ & 4.67 & 2.09 & 2.22 & 8.98 & $\begin{array}{r}0.520 \\
\pm 0.059\end{array}$ & $\begin{array}{r}0.232 \\
\pm 0.023\end{array}$ & 101.0 & $\begin{array}{r}0.518 \\
\pm 0.050\end{array}$ \\
\hline Overall & 4.51 & 1.84 & 2.46 & 8.81 & $\begin{array}{r}0.512 \\
\pm 0.032\end{array}$ & $\begin{array}{r}0.209 \\
\pm 0.012\end{array}$ & 104.4 & $\begin{array}{r}0.499 \\
\pm 0.027\end{array}$ \\
\hline $\begin{array}{l}\text { Control } \\
\quad(\text { Rep. } 1+2+3)\end{array}$ & 3.54 & 1.88 & 2.93 & 8.35 & $\begin{array}{r}0.424 \\
\pm 0.098\end{array}$ & $\begin{array}{r}0.225 \\
\pm 0.024\end{array}$ & 97.9 & $\begin{array}{r}0.424 \\
\pm 0.097\end{array}$ \\
\hline $\begin{array}{l}\text { High } \\
\quad(\text { Rep. } 1+2+3)\end{array}$ & 2.64 & 2.51 & 4.61 & 9.76 & $\begin{array}{r}0.270 \\
\pm 0.091\end{array}$ & $\begin{array}{r}0.257 \\
\pm 0.020\end{array}$ & 103.2 & $\begin{array}{r}0.294 \\
\pm 0.097\end{array}$ \\
\hline Low $($ Rep. $1+2+3)$ & 2.41 & 1.04 & 2.76 & 6.21 & $\begin{array}{r}0.388 \\
\pm 0.096\end{array}$ & $\begin{array}{r}0.168 \\
\pm 0.022\end{array}$ & 82.8 & $\begin{array}{r}0.342 \\
\pm 0.091\end{array}$ \\
\hline $\begin{array}{l}\mathrm{C}+\mathrm{H} \\
\quad(\text { Rep. } 1+2+3)\end{array}$ & 4.64 & 2.37 & 3.07 & 10.08 & $\begin{array}{r}0.461 \\
\pm 0.053 \\
\end{array}$ & $\begin{array}{r}0.235 \\
\pm 0.016\end{array}$ & 110.7 & $\begin{array}{r}0.477 \\
\pm 0.056\end{array}$ \\
\hline $\begin{array}{l}\mathrm{C}+\mathrm{L} \\
\quad(\text { Rep. } 1+2+3)\end{array}$ & 3.55 & 1.66 & 2.26 & 7.47 & $\begin{array}{r}0.475 \\
\pm 0.050\end{array}$ & $\begin{array}{r}0.223 \\
\pm 0.017\end{array}$ & 94.6 & $\begin{array}{r}0.455 \\
\pm 0.050\end{array}$ \\
\hline
\end{tabular}


Table 3 Estimates of variance components and genetic parameters for lean mass from data of generations 0-20

\begin{tabular}{|c|c|c|c|c|c|c|c|c|}
\hline \multirow[b]{3}{*}{ Lines } & \multicolumn{6}{|c|}{ Log transformed } & \multirow{2}{*}{\multicolumn{2}{|c|}{ Untransformed }} \\
\hline & $V_{A}$ & $V_{r}$ & $V_{\mathrm{F}}$ & $V_{\mathrm{p}}$ & \multirow{2}{*}{$\begin{array}{l}h^{2} \\
\pm \text { s.e. }\end{array}$} & \multirow[b]{2}{*}{$\begin{array}{l}c^{2} \\
\pm \text { s.e. }\end{array}$} & & \\
\hline & \multicolumn{4}{|c|}{$\left(\times 10^{-4}\right)$} & & & $\begin{array}{l}V_{\mathrm{p}} \\
\left(\mathrm{g}^{2}\right)\end{array}$ & $\begin{array}{l}h^{2} \\
\pm \text { s.e. }\end{array}$ \\
\hline $\begin{array}{l}\text { Rep. } 1 \\
\qquad(C+H+L)\end{array}$ & 50.6 & 16.3 & 27.2 & 94.1 & $\begin{array}{r}0.538 \\
\pm 0.036\end{array}$ & $\begin{array}{r}0.173 \\
\pm 0.018\end{array}$ & 8.34 & $\begin{array}{r}0.533 \\
\pm 0.033\end{array}$ \\
\hline $\begin{array}{l}\text { Rep. } 2 \\
\qquad(\mathrm{C}+\mathrm{H}+\mathrm{L})\end{array}$ & 50.0 & 22.0 & 24.6 & 96.6 & $\begin{array}{r}0.518 \\
\pm 0.038\end{array}$ & $\begin{array}{r}0.228 \\
\pm 0.018\end{array}$ & 8.40 & $\begin{array}{r}0.499 \\
\pm 0.032\end{array}$ \\
\hline $\begin{array}{l}\text { Rep. } 3 \\
\qquad(\mathrm{C}+\mathrm{H}+\mathrm{L})\end{array}$ & 47.9 & 20.5 & 24.2 & 92.6 & $\begin{array}{r}0.517 \\
\pm 0.040\end{array}$ & $\begin{array}{r}0.220 \\
\pm 0.018\end{array}$ & 8.55 & $\begin{array}{r}0.510 \\
\pm 0.045\end{array}$ \\
\hline Overall & 49.2 & 20.7 & 25.5 & 95.4 & $\begin{array}{r}0.516 \\
\pm 0.024\end{array}$ & $\begin{array}{r}0.217 \\
\pm 0.015\end{array}$ & 8.50 & $\begin{array}{r}0.507 \\
\pm 0.022\end{array}$ \\
\hline $\begin{array}{l}\text { Control } \\
\quad(\text { Rep. } 1+2+3)\end{array}$ & 51.2 & 20.2 & 29.5 & 100.9 & $\begin{array}{r}0.508 \\
\pm 0.071\end{array}$ & $\begin{array}{r}0.200 \\
\pm 0.021\end{array}$ & 8.49 & $\begin{array}{r}0.504 \\
\pm 0.069\end{array}$ \\
\hline $\begin{array}{l}\text { High } \\
\qquad \text { (Rep. } 1+2+3)\end{array}$ & 36.7 & 25.0 & 35.9 & 97.6 & $\begin{array}{r}0.376 \\
\pm 0.072\end{array}$ & $\begin{array}{r}0.256 \\
\pm 0.022\end{array}$ & 10.27 & $\begin{array}{r}0.312 \\
\pm 0.066\end{array}$ \\
\hline $\begin{array}{l}\text { Low } \\
\quad(\text { Rep. } 1+2+3)\end{array}$ & 36.2 & 14.3 & 28.7 & 79.2 & $\begin{array}{r}0.457 \\
\pm 0.069\end{array}$ & $\begin{array}{r}0.180 \\
\pm 0.017\end{array}$ & 5.65 & $\begin{array}{r}0.530 \\
\pm 0.073\end{array}$ \\
\hline $\begin{array}{l}\mathrm{C}+\mathrm{H} \\
\quad(\text { Rep. } 1+2+3)\end{array}$ & 54.7 & 23.3 & 26.0 & 104.0 & $\begin{array}{r}0.526 \\
\pm 0.035\end{array}$ & $\begin{array}{r}0.224 \\
\pm 0.013\end{array}$ & 10.28 & $\begin{array}{r}0.500 \\
\pm 0.031\end{array}$ \\
\hline $\begin{array}{l}\mathrm{C}+\mathrm{L} \\
\quad(\text { Rep. } 1+2+3)\end{array}$ & 43.1 & 18.1 & 27.0 & 88.2 & $\begin{array}{r}0.489 \\
\pm 0.038\end{array}$ & $\begin{array}{r}0.205 \\
\pm 0.012\end{array}$ & 6.47 & $\begin{array}{r}0.512 \\
\pm 0.036\end{array}$ \\
\hline
\end{tabular}

between the log-likelihood of the heterogeneous and the homogenous models are computed; doubled values can be compared with a chi-square to test between heterogeneous and homogeneous models. For both high and low lines there is evidence of a substantial and significant drop in genetic variance in later generations, even though fitting pedigrees enabled inferences back to the base population. There is also evidence of heterogeneity of a common environment variance, it being highest in high and lowest in low, the fit being significantly better for comparisons in which the first generations of selected lines are included with the control.

The predictions of breeding values from the REML analyses for each animal were averaged to show the mean genotype for each line each generation (Fig. 2). These were obtained using the model in which different $V_{\mathrm{A}}$ but the same $V_{\mathrm{C}}$ were fitted to each of the high/ control and low/control pairs over generations $0-20$ (the first set of estimates in the heterogeneous $V_{\mathrm{A}}$ and homogeneous $V_{C}$ blocks in Tables 4 and 5). The consistency of the pairs is shown by similar predictions for control line means. The curves also illustate the consistent differences among the replicates after allowing for environmental sampling. The mean divergence at generation 20 of 0.53 units on the log scale is equivalent to a 1.7-fold high/low ratio, as observed (Fig. 1).

\section{Discussion}

The estimate of heritability of lean mass in the base population of approximately 0.5 is close to that obtained by regression of response on selection differential from the first 11 generations (Sharp et al., 1984). In view of the fact that selection was weak, within families in only one sex, the short-term change of variance caused by selection ('Bulmer effect') is likely to be small (Bulmer, 1980) and so the realized heritability estimate is little biased.

It is clear from the analyses over successive generations, however, that genetic variances reduced during the course of the experiment, by amounts which could not be ascribed to the Bulmer effect or to inbreeding because these are catered for by the REML analysis with the animal model. Substantial changes were also found in lines selected for an index of food intake and body weight selected from the same base population (Meyer \& Hill, 1991). The values in Tables 4 and 5 show different combinations of generations $0-20$, 5-20, 8-20 and 15-20 and these can be extended by making the simple assumption that these are subsets of results of individual generations weighted by numbers recorded. Thus approximate estimates of $V_{\mathrm{A}}\left(\times 10^{-4}\right.$ on the log scale) are as follows. 
Table 4 Estimates of variance components and genetic parameters for lean mean in control $(\mathbf{C})+$ high $(\mathbf{H})$ lines for log-transformed data of generations $0-20$, together with log-likelihood ratios, from analyses with both homogeneous and heterogeneous additive genetic and common litter variance assumptions

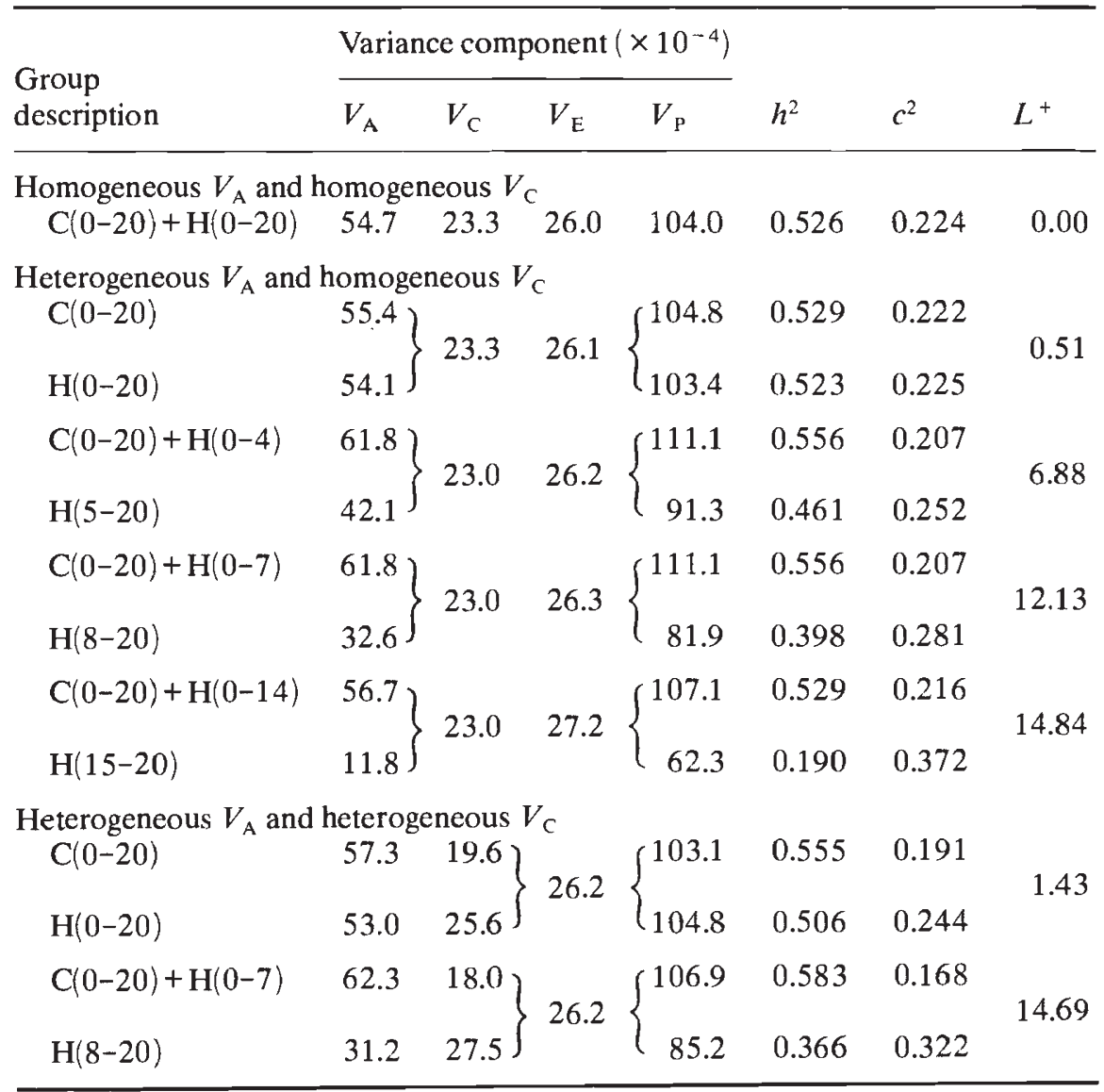

$L^{+}=$Log-likelihood ratio relative to fitting homogeneous variance.

$\begin{array}{lllll}\text { Generations } & 0-4 & 5-7 & 8-14 & 15-20 \\ \text { High line } V_{\mathrm{A}} & 71 & 51 & 42 & 12 \\ \text { Low line } V_{\mathrm{A}} & 48 & 28 & 20 & 15\end{array}$

Changes are clearly quite substantial.

At first sight the results of the generation $0-7,0-20$ and heterogeneous variance analyses are inconsistent (Tables 2-5), in that use of the data from generations 7-20 leads to an increase in heritability but the heterogeneous variance analyses suggest a decline in heritability in later generations. Comparison of individual and combined analyses of lines suggests that the heritability estimate from differences between high and control lines decreases from 0.71 in generations $0-7$ to 0.57 in generations 7-20. As the latter depends on both early and later responses, it is less surprising that the heritability estimate declines.

The observed responses (Fig. 1) and responses predicted from mean breeding values (Fig. 2) show very good agreement, despite the fact that the predicted variances were assumed to remain constant. A similarly good fit could be obtained with other models. This is because, in this experiment where, for example, high and control lines are compared, their observed difference in means is already an excellent predictor of breeding value. If an incorrect heritability is used, the expected response $\left(h^{2} \times\right.$ selection differential $)$ differs from that realized; but this is attributed to genetic drift and is also incorporated into subsequent generations. The likelihood of the data is much more clearly affected by the use of incorrect parameters. If, however, only a single line without a control had been maintained, the predicted response would have been highly sensitive to the estimate of heritability; the difference between predicted and actual response would have been attributed to environmental change.

The response to selection on body weight shown in Fig. 1 and analysed here is typical of several other selection experiments on body weight or growth rate of mice [see reviews by Roberts (1965), Eisen (1974, 
Table 5 Estimates of variance components and genetic parameters for lean mean in control $(C)+$ low $(L)$ lines for log-transformed data of generations 0-20, together with log-likelihood ratios, from analyses with both homogeneous and heterogeneous additive genetic and common litter variance assumptions

\begin{tabular}{|c|c|c|c|c|c|c|c|}
\hline \multirow{2}{*}{$\begin{array}{l}\text { Group } \\
\text { description }\end{array}$} & \multicolumn{4}{|c|}{ Variance component $\left(\times 10^{-4}\right)$} & \multirow[b]{2}{*}{$h^{2}$} & \multirow[b]{2}{*}{$c^{2}$} & \multirow[b]{2}{*}{$L^{+}$} \\
\hline & $V_{\mathrm{A}}$ & $V_{\mathrm{C}}$ & $V_{\mathrm{E}}$ & $V_{\mathrm{P}}$ & & & \\
\hline \multicolumn{8}{|c|}{ Homogeneous $V_{\mathrm{A}}$ and homogeneous $V_{\mathrm{C}}$} \\
\hline$C(0-20)+L(0-20)$ & 43.1 & 18.1 & 27.0 & 88.2 & 0.489 & 0.205 & 0.00 \\
\hline \multicolumn{8}{|c|}{ Heterogeneous $V_{\mathrm{A}}$ and homogeneous $V_{\mathrm{C}}$} \\
\hline $\mathrm{C}(0-20)$ & 57.1 & \multirow{2}{*}{17.2} & \multirow{2}{*}{27.4} & 101.7 & 0.562 & 0.169 & \multirow{2}{*}{10.74} \\
\hline $\mathrm{L}(0-20)$ & & & & 78.3 & 0.431 & 0.220 & \\
\hline$C(0-20)+L(0-4)$ & 53.2 & \multirow{2}{*}{17.6} & \multirow[b]{2}{*}{27.5} & 98.4 & 0.541 & 0.179 & \multirow[b]{2}{*}{19.00} \\
\hline $\mathrm{L}(5-20)$ & & & & 68.8 & 0.344 & & \\
\hline $\mathrm{C}(0-20)+\mathrm{L}(0-7)$ & 49.9 & \multirow[b]{2}{*}{17.7} & \multirow[b]{2}{*}{27.6} & 95.3 & 0.524 & 0.186 & \multirow[b]{2}{*}{18.20} \\
\hline $\mathrm{L}(8-20)$ & 18.3 & & & 63.7 & 0.288 & 0.279 & \\
\hline$C(0-20)+L(0-14)$ & 45.8 & \multirow{2}{*}{18.4} & \multirow{2}{*}{26.8} & 91.0 & 0.503 & 0.202 & \multirow{2}{*}{7.65} \\
\hline $\mathbf{L}(15-20)$ & 15.0 & & & 60.2 & 0.250 & 0.305 & \\
\hline \multicolumn{8}{|c|}{ Heterogeneous $V_{\mathrm{A}}$ and heterogeneous $V_{\mathrm{C}}$} \\
\hline $\mathrm{C}(0-20)$ & 55.9 & 19.6 & \multirow{2}{*}{27.2} & $(102.7$ & 0.544 & 0.191 & \multirow{2}{*}{11.13} \\
\hline $\mathbf{L}(0-20)$ & 34.6 & 15.9 & & 77.7 & 0.445 & 0.205 & \\
\hline $\mathrm{C}(0-20)+\mathrm{L}(0-7)$ & 49.0 & 21.8 & \multirow{2}{*}{27.3} & 98.1 & 0.499 & 0.222 & \multirow{2}{*}{20.23} \\
\hline $\mathbf{L}(8-20)$ & 20.7 & 14.4 & & 62.4 & 0.331 & 0.231 & \\
\hline
\end{tabular}

$L^{+}=$Log-likelihood ratio relative to fitting homogeneous variances.

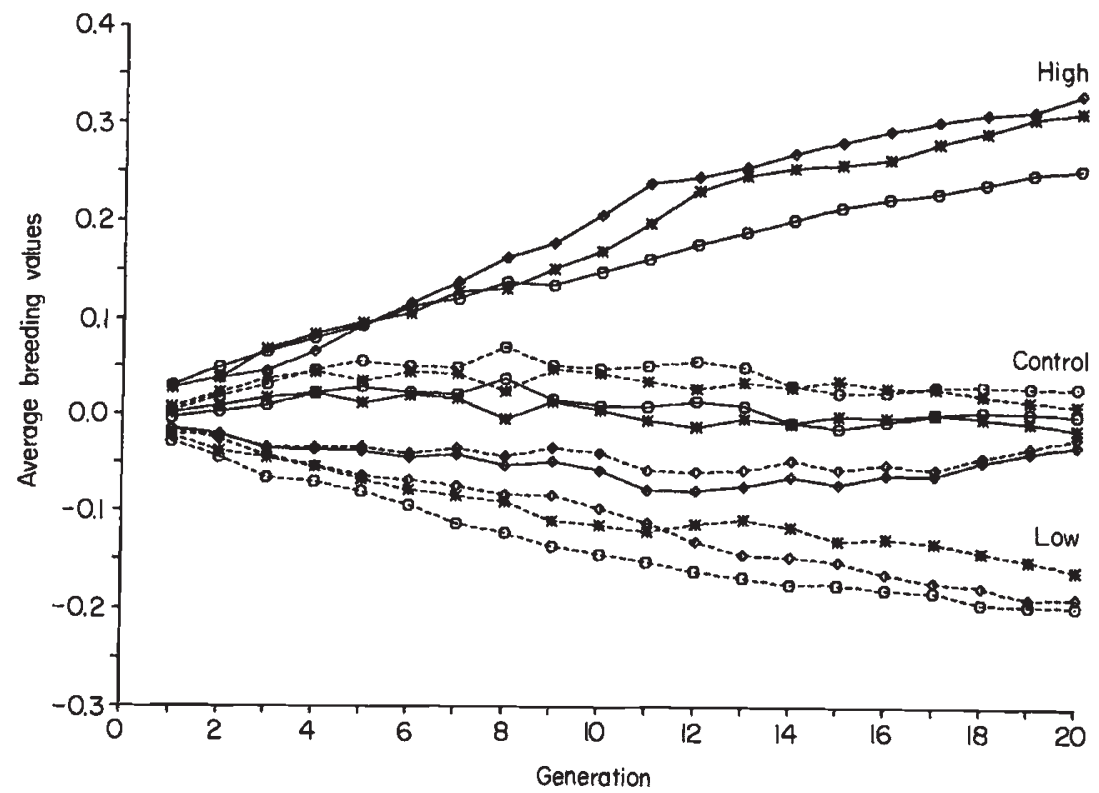

Fig. 2 Response to selection for lean mass in each replicate of each direction of selection calculated from mean breeding values from the REML analysis. Analysed assuming heterogeneity of $V_{\mathrm{A}}$ throughout generations $0-20$ for control + high (—) and control + low $(--)$ lines. Replicate $1(\diamond), 2(0), 3(*)$. 
1989), McCarthy (1982)], i.e. heritability in the region 0.3-0.6 without major apparent declines in response over the course of selection for less than 20 generations. In the present study the REML analysis with an animal model revealed trends in the underlying genetic parameters which may be missed in a conventional analysis based on realized heritabilities.

The infinitesimal model assumption therefore broke down, even though selection was weak. The methods give no pointer as to what changes took place, but it is most likely that not all genes influencing predicted lean mass had a sufficiently small effect that their changes in gene frequency and consequent changes in variance were negligible. The model also assumes that loci are unlinked, so disequilibrium caused by selection among linked loci contributes to changes in variance. Note that the model is solely of additive gene action at autosomal loci: epistatic and dominance components are assumed negligible and it is uncertain how their presence, let alone changes in them, influence estimates of variance referred back to the base population.

There is some evidence that sex-linked effects influence responses in these lines. After a further 14 generations of selection for body weight (Beniwal et al., 1992) reciprocal $F_{1}$ crosses and backcrosses were made of the high and low lines. It was found that the $\mathrm{X}$ chromosome (which comprises approximately 5 per cent of the mouse genome) was responsible for approximately 25 per cent of the divergence between the high and low lines (Hastings, 1990; Veerkamp, 1991). Subsequent unpublished analyses have also shown that this effect was present in all the original three replicate lines, and did not result from mutation. Selection up to generation 20 was restricted to males in which sexlinked genes are hemizygous and dominance effects absent. Higher selection pressure is thereby, in effect, put on sex-linked genes (Grossman \& Eisen, 1989) although an alternative explanation, that of a single sexlinked 'major gene', cannot be rejected.

The model did not include any component for new variation derived from mutation. Extensive data on Drosophila suggest mutational heritabilities $\left(V_{\mathrm{M}}\right)$ $V_{E}=$ ratio of variance per generation from mutation to environmental variance) of about 0.001 for bristle number (Lynch, 1988). Data are scanty for mammals, but for body weight at 6 weeks this could be as high as 0.01 (Keightley \& Hill, 1990). If mutation rates are substantial, the reduction in initial variance is greater than calculated in the present analysis.

Terms for genetic variance in the base population and for mutation were therefore included in the animal model (following Keightley \& Hill, 1990) so both could be estimated. This was performed first for the control replicates alone, because estimates of the parameters would not be biased by changes due to selection. The likelihood was very flat over a range of values of $V_{\mathrm{M}} / V_{\mathrm{A}}$ $\left(\doteq V_{\mathrm{M}} /\left(V_{\mathrm{C}}+V_{\mathrm{E}}\right) \doteq 2 V_{\mathrm{M}} / V_{\mathrm{P}}\right.$ because $\left.h^{2} \doteq 0.5\right)$ from -0.025 to 0 to 0.01 , with log-likelihood deviations of $0.74,0.23$ and 0.74 , respectively from the maximum at $V_{\mathrm{M}} / V_{\mathrm{A}}=-0.007$. Clearly this experimental design does not enable mutational and initial variance to be separated with useful precision. The analysis was repeated using high and control lines. In this case the $M L$ estimate of $V_{\mathrm{M}} / V_{\mathrm{A}}$ was substantially negative $(<-0.02)$, highly significantly less than $V_{\mathrm{M}} / V_{\mathrm{A}}=0$ from a likelihood ratio test. The interpretation of this result is not that mutation reduces variance, but that in later generations the covariance among relatives declines further than expected from inbreeding and selection in the infinitesimal model. Variation from mutation accumulates quadratically so this negative 'mutational variance' is not a simple linear measure of decline in variance.

It was observed that the component of variance attributed to common environment (litter, $c^{2}$ ) also changed, becoming substantially higher in the high than low lines over the 20 generations. Litter size is higher in the high line (Brien et al., 1984; Beniwal et al., 1992) as are birth and weaning weights of the young mice, so greater demands are imposed on their dams and the higher $c^{2}$ component may reflect greater expression of dams' maternal ability in the high than low lines, a point discussed further in the subsequent paper. The common environmental variance is confounded with non-additive genetic variance, so genetic changes could also have contributed to the apparent changes in $V_{\mathrm{C}}$ and $c^{2}$. The highest coefficient of non-additive genetic components in the covariance of full sibs is onequarter for the dominance and additive $\times$ additive terms. It would, therefore, require very large changes in such components to effect the changes found in the estimates of $V_{\mathrm{C}}$ and $c^{2}$; so it seems reasonable to assume that the causes were mainly environmental.

The estimates of parameters differed among the replicates, but no more than would be expected from the standard errors estimated within replicates (i.e. generation $7, h^{2}$ range 0.08 , average s.e. $=0.05$; generation $20, h^{2}$ range 0.02 , average s.e. $=0.04$ ). This illustrates the utility of the animal model in obtaining standard errors without replications and without making very crude assumptions about independence of errors in regression (realized heritability) or of correcting such estimates (Hill, 1972).

In view of the magnitude of the changes in genetic and non-genetic variances observed it is clear that reestimation of parameters should be undertaken within breeding programmes employing Best Linear Unbiased Prediction (BLUP) so that current values, relevant to comparison of animals available for selection, are used. The method by which changing para- 
meters should be incorporated in data spanning many generations needs investigation, however. Fortunately, comparisons among contemporaries are fairly robust against poor estimates of heritability, those among noncontemporaries and estimates of genetic trends in selected populations maintained without a contemporaneous unselected control are less so.

The analyses presented here of data from selection experiments have included novel features, in particular the adoption of assumptions of heterogeneity of variance in selected and control or in divergent lines. This enabled environmental effects common to generation means to be eliminated and all pedigrees fitted, so efficient estimates could be obtained. Such analyses showed more unequivocally the effects of selection on variance than did those on individual lines. There is clearly scope for more sophisticated analyses to track the path of change in variance, but experiments would need to be large for such analyses to have useful precision. It would also be useful to extend beyond the infinitesimal model, for example, to incorporate segregation of one or more genes of large effect (Hill \& Knott, 1990); but such analyses are computationally demanding, especially if more than one locus is fitted. They might go further toward understanding the biology of the trait under selection, in contrast to the analysis here which has concentrated on the animal and the trait as a model for investigation at the statistical level of responses to long-term selection.

\section{Acknowledgements}

This work was supported by a grant from the Agricultural and Food Research Council. BKB was in receipt of a Commonwealth Scholarship. We are grateful to Douglas Falconer and an anonymous referee for helpful comments.

\section{References}

BENIWAL, B. K., HASTINGS, I. M., THOMPSON, R. AND HILL, W. G. 1992. Estimation of changes in genetic parameters in selected lines of mice using REML with an animal model. 2. Bodyweight, body composition and litter size. Heredity, 69, 361-371.

BRIEN, F. D., SHARP, G. L., HILL, W. G. AND ROBERTSON, A. 1984. Effect of selection on growth, body composition and food intake in mice. Genet. Res., 44, 73-85.

BULMER, M. G. 1980. The Mathematical Theory of Quantitative Genetics. Clarendon Press, Oxford.

EISEN, E. J. 1974. The laboratory mouse as a mammalian model of growth. Proc. 1st World Congr. Genet. Appl. Livest. Prod., Madrid, 1, 467-492.

EISEN, E. J. 1989. Selection experiments for body composition in mice and rats: A review. Livest. Prod. Sci., 23, 17-32.

FALCONER, D. S. 1973. Replicated selection for body weight in mice. Genet. Res., 22, 291-321.
GROSSMAN, M. AND EISEN, E. J. 1989. Inbreeding, coancestry, and covariance between relatives for $\mathrm{X}$-chromosomal loci. J. Hered., 80, 137-142.

HASTINGS, I. M. 1990. An investigation of mouse lines selected on body weight for the presence of major genes. Proc. 4th World Congr. Genet. Appl. Livest. Prod., Edinburgh, 13, 317-320.

HASTINGS, I. M. AND HILL, W. G. 1989. A note on the effect of different selection criteria on carcass composition in mice. Anim. Prod., 48, 229-233.

HILL, w. G. 1972. Estimation of realised heritabilities from selection experiments. I. Divergent selection. Biometrics, 28, 747-765.

HILL, W. G. AND KNOTT, s. 1990. Identification of genes with large effects. In: Gianola, D. and Hammond, K. (eds) Advances in Statistical Methods for Genetic Improvement of Livestock. Springer-Verlag, Berlin. pp. 477-494.

KEIGHTLEY, P. D. AND HILL, w. G. 1990. Estimating new mutational variation in growth rate of mice. Proc. 4th World Congr. Genet. Appl. Livest. Prod. Edinburgh, 13, 484-487.

LYNCH, M. 1988. The rate of polygenic mutation. Genet. Res., 51, 137-148.

McCARTHY, J. C. 1982. The laboratory mouse as a model for animal breeding. A review of selection for increased body weight and litter size, Proc. 2nd World Congr. Genet. Appl. Livest. Prod., Madrid, 5, 66-83.

MEYER, K. 1988. DFREML-Programs to estimate variance components for individual animal models for Restricted Maximum Likelihood (REML). User Notes. Institute of Animal Genetics, University of Edinburgh, Edinburgh, U.K.

MEYER, K. AND HILL, w. 1991. Mixed model analysis of a selection experiment for food intake in mice. Genet. Res., 57, $71-81$.

PATTERSON, H. D. AND THOMPSON, R. 1971. Recovery of interblock information when block sizes are unequal. Biometrika, 58, 545-554.

ROBERTS, R. C. 1965 . Some contributions of the laboratory mouse to animal breeding research: Part 1. Anim. Breed. Abstr., 33, 339-353.

SHARP, G. L., HILL, W. G. AND ROBERTSON, A. 1984. Effects of selection on growth, body composition and food intake in mice. I. Responses in selected traits. Genet. Res., 43, 75-92.

SøRENSEN, D. A. AND KENNEDY, B. W. 1984. Estimation of genetic variances from selected and unselected populations. $J$. Anim. Sci., 59, 1213-1223.

VAN DER WERF, J. H. J. AND DE BOER, I. J. M. 1990. Estimation of additive genetic variance when base populations are selected. J. Anim. Sci., 68, 3124-3132.

VEERKAMP, R. F. 1991. An investigated for the presence of a major gene in mouse lines selected on body weight. Ing. Thesis, Wageningen Agricultural University, The Netherlands.

VISSCHER, P. M. AND THOMPSON, R. 1990. REML estimates of parameters for fat yield in pedigree herds in the U.K. using an individual animal model: Male and female heritability estimates. Proc. 4th World Congr. Genet. Appl. Livest. Prod., Edinburgh, 14, 233-236. 